\title{
Prelude to Alliance: Britons and Yankees in the Far Northwest, 1867-1917
}

\author{
Preston Jones
}

John Brown University

Abstract: In the late-nineteenth and early-twentieth centuries the United States became a significant imperial power with which an overstretched British Empire did not want conflict. The planting of numerous American flags in the Canadian Yukon, and especially in Dawson City, symbolized this dynamic, which was accompanied by some tension and apprehension on the part of British-Canadian authorities. At the same time, hints at a future friendly alliance between the United States and Britain can be seen in the mingling, in the Yukon Territory, of Yankees, Britons, and Canadians who all shared (among other things) a common literary heritage. Among these hints was an implausible but sincere proposal on the part of a US Congressman for the United States to cede the Alaska Panhandle to Canada. This article is part of a special collection of papers originally presented at a conference on "The North and the First World War," held May 2016 in Whitehorse, Yukon.

The Northern Review 44 (2017): 293-326 


\section{Introduction}

"I believe I must send you a line ... to tell you the changes that are coming over us here." William Bompas, Anglican priest and future bishop, was writing in August 1869. "Since last week," he continued, "Fort Youcon [sic] ... has progressed at least a century in civilisation, science \& art." The change had been sparked by the arrival of "a small steam tug" carrying merchants from San Francisco and, more importantly, an American army officer ordered to "claim this fort for the American Government in case it appears to be in American Territory." ${ }^{1}$

Bompas faintly hoped that Fort Yukon (Gwichyaa Zheh), just above the Arctic Circle, was not situated on what had been Russian territory before the United States purchased Alaska in 1867, but by letter's end he was more candid, supposing that there was "little doubt that this fort is over the American boundary and the Hudson's Bay Company will ... have to give up the fort to the Yankees." Bompas noted that, having "paid so dear for this new Territory," the Yankees were "determined to keep it to themselves."

If it is true that Bompas was a highly devoted if also "cantankerous and self-righteous loner" who had imposed on himself a kind of "selfimposed exile" in the Far North, then it must have been unpleasant to find himself among agents of Yankee rule. ${ }^{2}$ And, like other British-Canadian authorities, he smelled a more extensive design, supposing that "it was only with a view of securing a sort of back entrance into the British North American possessions that the Yankees paid so dear for their new Territory of Alaska."

There is no evidence that the United States government planned to annex what would become the Yukon Territory, as Bompas suggested, though there are plenty of reasons to assume that such a thing could have happened. The San Francisco Evening Bulletin had asserted that the "extension of our flag to the northernmost point of the continent ... will deal a fatal blow to British interests in the North Pacific," ${ }^{3}$ and the Times of London took it for granted that a primary motivation behind the purchase was the desire of the United States to expand its rule: "The aspiration of the United States to absorb the whole of North America is no secret." ${ }^{4}$ In late 1867 a US senator from Minnesota (and future secretary of war), Alexander Ramsey, proposed that the United States should purchase the western half of present-day Canada. ${ }^{5}$ 
Some Americans assumed that the annexation of British Columbia was inevitable. ${ }^{6}$ A couple months after Bompas met Captain Raymond at his Arctic fort, "forty prominent citizens of Victoria" addressed an appeal to President Ulysses S. Grant "praying for the annexation of British Columbia to the United States." ${ }^{7}$ Bompas's assumption that American designs in the Far Northwest extended well beyond merely securing Alaska was echoed in ideas widely, if not officially expressed.

Captain Raymond did his work; he determined that Fort Yukon was indisputably in Alaska. The Yankee flag went up there, and what Leroy McQuesten had called "a flourishing business in the fur trade," centred at the fort, fell from British hands. ${ }^{8}$

Bompas's important letter is a starting point for reflections on BritishUS relations in the Far Northwest. An interesting end point is a littleremembered scheme to cede the Alaskan panhandle to Canada. Both episodes-Bompas witnessing the raising of the US flag at Fort Yukon and, nearly fifty years later, Canadians hoping for a generous real estate transfer from the United States that would give the Yukon Territory a direct link to the Pacific-illustrate the power of the United States relative to Canada and, in hemispheric terms, Britain.

Bompas saw the United States as a relentless, self-absorbed power. "There has actually been a serious correspondence between the President \& Congress of the US and their Secretaries of State about this insignificant fort, so pleased is brother Jonathan [the US] with this chance of making patient John Bull [Britain] march off his premises." In fact, the US president and Congress did not focus on Fort Yukon, but Bompas's sentiment was a general one. Not long after the turn of the twentieth century, Prime Minister Wilfrid Laurier observed that Canadians lived "beside a great neighbor who ... are very grasping in their national actions" and were "determined on every occasion to get the best in any agreement which they make." ${ }^{10}$ There is not much of international friendship in such words.

So the British-American story in the Far Northwest was marked by tension, largely the result of Canadians feeling stepped on or threatened by Americans. But in the years between 1865 and 1917 Americans in the Far Northwest did not have all the power, and Canadians did not accept whatever Americans offered. There was tension but also collaboration; there was irritation but also admiration. There was difference but also a common culture forged in hardship, purpose, and a common language and literature. There was quiet adaptation to different ways of being, and sometimes there was conscious cultural conversion. Along the 
Yukon River, up the Chilkoot and White passes, in the roads of Skagway, Dawson, and Forty Mile, international and cultural differences sometimes mattered, but much of the time they did not. An instance described by Alaska missionary Julia McNair Wright is instructive. There was a funeral at Wrangell. About sixty of a deceased missionary's "Indian friends" turned out for the service. A procession was formed and a search was made for a US flag to lead the way. But "having no United States flag," Wright says, "the leader carried a British ensign" instead. ${ }^{11}$

\section{People}

It is of course too tidy to summarize human affairs in the Far Northwest over a fifty-year period as merely British and Yankee. Israel Russell wrote in the Bulletin of the American Geographical Society that the Yukon seemed to host "representatives of nearly every nation on earth."12 The Catholic missionary William Judge noted that the Yukon gold rush attracted men from "every part of the world," adding that he had met "a Catholic from Damascus." ${ }^{13}$ Elizabeth Robins's diary includes references to a "negro chambermaid," an unnamed "southern woman," a ship officered by English and Scots but with a crew of Chinese, a Dane, a "grinning fat Swede," a pleasant if boorish Norwegian woman, an "Englishman from the Hawaiian Islands," and a "shrewd, reckless [and] desperate" French Canadian. ${ }^{14}$ Writing in the 1860s, Robert Kennicott suggested that Englishmen, Gaels, Norwegians, and French adopted the common character of voyageur. ${ }^{15}$ And literature from that time and region regularly notes the essential work and friendship of Indigenous peoples. To cite one example of hundreds, before leaving Skagway for the Yukon, Anna DeGraf (herself a German immigrant) hired "some Indians" who led the way and carried much of her party's stores. ${ }^{16}$

Yet, for all the human diversity in the Far Northwest in the late nineteenth and early twentieth centuries, the dominant public cultures were British and American. The Census of 1870 counted some 391 persons in Sitka (Shee Atika), Alaska, only thirty-two of whom had been born in the United States (the census did not count the Indigenous people in the area). ${ }^{17}$ Yet the town's public culture was American in tone and outlook. Given English visitor Sophia Cracroft's several criticisms of Americans and their manners - "18 hours of American companionship ... is not a desirable condition" - one might have assumed that Sitka was inhabited primarily by Yankees. ${ }^{18}$

As for the other side of the border, while a review of the many hundreds of photographs taken in the Far Northwest and preserved in books, 
museums, and archives occasionally reveals other national flags, the Stars and Stripes and banners bearing the British Union Jack in one form or another are ubiquitous. Often the two emblems were found side by side, such as when the pulpit in a temporary church was draped by "British and American flags" or when the owner of a new saloon wanted to purchase both banners in order to appeal to a nationally mixed clientele. ${ }^{19}$ It is true that many did not personally pledge allegiance to these flags, but it is also true that these flags represented the most influential cultures. As for what settlers, miners, and visitors of European origin living in the Yukon Territory called themselves, the terms British, English, and Canadian were frequently interchangeable.

\section{Empires in Transition}

The context of the Far Northwest in the years 1867-1917 is one of empires in transition..$^{20}$ In this period the British Empire grew into the largest collection of colonies the world had ever seen. Present day Sudan, Nigeria, Uganda, and Kenya, among other Africa territories, came under the British flag. In Asia, Britain held Hong Kong, Burma, India, and Sri Lanka, among other places. In the Americas, the Union Jack waved over Jamaica, Barbados, present-day Belize, British Guiana, and, of course, Canada and Newfoundland.

The flag of Hawaii reminds us that, had it not been for the United States, Britain's holdings might have been even more extensive. As a plaque posted next to a retired Hawaiian flag at the museum in Lahaina, Hawaii, concisely puts it: "The Union Jack represents Hawaii's historic ties with Great Britain." Hawaii's flag is a reminder that Britain's one-time ideal was to possess, or at least to be pre-eminent, in the Hawaiian Islands. Thirty-one years before, in the same year the United States purchased Alaska, the New Hampshire Patriot and Gazette interpreted American trade agreements with Hawaii as a triumph of "American diplomacy over the scheming designs of ... England," adding that, in terms of commercial importance, trade with Hawaii far outweighed "the recent treaty by which this country obtained possession of Russian America," as Alaska continued to be called for a short time. ${ }^{21}$

In a perfect imperial world, Britain also would have liked to control the outstanding harbour at Subic Bay in the Philippines. American observers knew or assumed this, and a few proposed trading the Philippines to Britain in exchange for Canada. ${ }^{22}$ Others noted that Canada's vulnerable position, situated alongside the United States, would prevent Britain from pressing its interests too hard if they conflicted with US desires. A 
thick and impressive book about the Spanish American War, somehow completed and published before the short war ended, made this point, observing that when

Great Britain offered her friendship to induce the United States to take [the Philippines] and be a supporter in keeping open to commerce the ports of China, she was well aware that [the US] would have a hostage to hold. Canada, with its great railway system, giving England communication with Hong-Kong and Australia, of great importance in ... times of difficulty, lies beside the United States, full collateral to secure the performance of honest obligations. ${ }^{23}$

So the United States took Hawaii, though many Britons had wanted it, and Britain did not stand in the way of the United States staying in the Philippines after the defeat of the Spanish there, partly for fear of what might happen in Canada if Americans were irked.

Then there was the case of the Panama Canal. The influential American naval theorist Alfred Thayer Mahan observed that mastery of the oceans depended on sea power and that sea power depended on the possession of "determining positions," or strategically vital locations. ${ }^{24}$ Strategists knew that Britain wanted a Central American canal. The British government knew, in turn, that such a canal was a "more direct and more urgent" interest of the United States ${ }^{25}$; and if the US were to take the lead in the construction of a canal crossing Nicaragua or Panama (then part of Columbia), "principal questions affecting the integrity or security of the British Empire [were] not involved seriously." ${ }^{26}$ In the Clayton-Bulwer Treaty of 1850, the United States and Britain agreed that a future canal would be jointly operated and defended. But when the US president Theodore Roosevelt went personally to Panama to operate a dirt-moving machine, he did not consult the government in London. A British observer wrote, "We ought not to be found in America's way where our interests are secondary and hers are supreme."27

Hawaii, the Philippines, the Panama Canal. We add Venezuela. A crisis of 1895 involved the border between British Guiana and Venezuela, drawn tentatively in 1840 and never accepted by the South American country. The frontier's location mattered because it determined control of the mouth of the Orinoco River. Discovery of gold in Venezuela heightened interest in determining the border's place and contours.

The problem was far removed from the United States but not from the reach of the Monroe Doctrine, a US assertion since the 1820s that 
the United States would see attempts at further European colonization in the Western Hemisphere as an act hostile to the United States. By the 1890s the understanding of the doctrine's principle had been expanded to signify that that any European aggression in the Western Hemisphere would be considered an infringement on American interests. President Grover Cleveland, who had opposed the annexation of Hawaii and the idea of a canal in Panama controlled only by the Americans, supported a broad interpretation of the Monroe Doctrine. If Britain did not submit the boundary question to arbitration and opted instead to press the matter militarily, the US government suggested, it could find itself at war with the United States. Britain took the matter to arbitration.

Each of these events - the Venezuela crisis, the annexation of Hawaii, the occupation of the Philippines, and the beginning of work on the Panama Canal-took place at or near the time thousands of Americans walked, climbed, and boated into British territory in the American continent's Far Northwest. Challenged as Britain was at the time by troubles in Sudan, South Africa, Afghanistan, and elsewhere, Britain's disposition toward the Americas was increasingly hands off. "Vast as were England's resources," says one writer, "she could not face the whole world at once." 28 The British Empire continued to grow in the period under study, though not at the rate it might have without the United States as a counterforce in the Pacific and Western Hemisphere.

With the 1867 purchase of Alaska, whose Aleutian chain terminated in the Northwest Pacific, the United States became an Asian power. Later that year the US possessed Midway Atoll. By 1900, Puerto Rico in the Atlantic, and Guam, American Samoa, and several other Pacific islands gathered, with Hawaii and the Philippines, under the Stars and Stripes. The Americans who rumbled into the Yukon Territory represented this rising power.

\section{Flags \& Tension}

American action often involved flag planting. When "the Stars and Stripes shall flaunt at Fort Yukon," Spencer Baird of the Smithsonian Institute said, the United States would be able to tap and exploit the "wonderfully plentiful" resources that had already benefited British traders..$^{29}$ Unquestionably, posting one's national flag where another had been amounted to an assertion and a kind of victory. This was illustrated by a Yukon soldier's First World War poem: his boys would not waver, he wrote, until "we nail the Union Jack on the Kaiser's chimney." ${ }^{30}$ No such provocation was meant at peaceful Fort Yukon, but a message of 
power was clear. The British had known for more than two decades that the fort was on Russian soil, but Russia had never had the resources to do anything about it.

Neither did Russian authorities in Alaska prevent the planting of American flags. George Adams, an employee with the Western Telegraph expedition of 1865-66, wrote of posting an American flag atop "a ten foot high ice heap." The pole to which the flag was attached rose an additional ten feet. "I was on November $7^{\text {th }}$, 1865," he wrote, "the first American ever on the Kvihpak [Yukon] River," and "mine [was] the first American Flag that was ever raised on that river, or in the interior of that country." The act was sealed with a twenty-one gun salute. ${ }^{31}$

The celebration of a first flag's raising in a mostly unsettled area is easy to understand, but Americans devoted energy to flag planting and maintenance throughout the period under study. The Catholic missionary William Judge wrote in 1891 of a "nine-foot American flag" posted in front of a tent at St. Michael. He reported-and myriad archived photos confirm - that steamers on the Yukon often flew multiple American flags. He wrote of Indigenous children practicing drill "as in a company of soldiers with wooden guns and an American flag." ${ }^{32}$ At Eagle City, near the Yukon Territory border, Elizabeth Robins spied a "huge American flag" (as compared to a "nice little library"). ${ }^{33}$ Elsewhere she posed by a flag that was small but raised high on a posted branch that had been towed to a treeless summit for display. ${ }^{34}$

Of course, Nome and other Alaskan towns "blossomed out with flags and bunting" on the Fourth of July. ${ }^{35}$ An Independence Day photo taken in Nome in 1915 reveals at least twenty-five flags in an area of perhaps twenty square meters. ${ }^{36} \mathrm{~A}$ comparable photo from fifteen years before shows fewer flags, but the eight or so that are visible make a clear statement about national identity. ${ }^{37}$

Perhaps more surprising is that the same seemed to be the case in Dawson, British territory, in the last years of the nineteenth century. A photo of a Dawson parade depicts a mix of flags, though the tallest one visible is American. ${ }^{38}$ Another holiday photo subtitled "pole vaulting contest" shows three large flags, all of them Uncle Sam's. ${ }^{39}$ A different image shows horses stuck in mud and a crowd of men standing around. In the background one sees a British flag and an American flag, the latter much larger. ${ }^{40}$ In some cases, British flags were posted above the Stars and Stripes on poles, though the US flag was usually larger. ${ }^{41}$

This kind of thing had been seen before. In July 1899, American "excursionists" from North Dakota and Minnesota arrived in Winnipeg 
for a large fair and an "American flag was hoisted over the principal places and everything [looked] American." ${ }^{22}$ Such was the stuff of inter-regional celebration. On other occasions, the British American response was more ambiguous if still generally positive, such as when "loyal Britishers" at a play in Vancouver waved "the brave old union Jack" and "our own loved Canadian ensign" in a planned response to a proliferation of American flags on the stage presided over by the American actress Katie Putnam. A writer for the Vancouver Daily World wrote that what looked like national counter assertion was actually an expression of "racial love." Would it not have been wonderful, the writer continued, if "the Star Spangled Banner and the Union Jack had been held together in the arm that had waved three cheers for the Anglo-Saxon race"? ${ }^{43}$

Writing from Dawson in July 1899, and while still identifying herself as American, Martha Black described a similar international sentiment. The Canadians in Dawson were as "delighted to help us celebrate our national holiday as we were to join with them on Dominion Day (July 1) ... . The Fourth was heralded in by a gunshot ... and 10,000 Americans and Canadians paraded up and down singing alternately 'My Country 'tis of Thee,' and 'God Save the Queen'."'44

For the good spirit Black describes, it seems clear that in Dawson's first years Americans did not seek permission to raise US flags on British territory, and also that Canadian authorities did not usually require them to. There appear to have been exceptions. An American official at Juneau reported in 1901 that American children in Dawson were forbidden from displaying US flags at school, ${ }^{45}$ and Mary Hitchcock, an American tourist in Dawson, records that the Canadian collector of customs, D.W. Davis, who shared an office space in Dawson with the US consul James McCook, "refused to serve where the American flag was allowed to fly." 46

Hitchcock's claim is corroborated by newspaper accounts. "General McCook's quarters were visited continually by American citizens who congratulated themselves upon the arrival here of an official representative of their government in terms that offended the ears of the Canadian official." This, so the newspaper story suggests, set the stage for a confrontation. 
[Davis:] Mr. Cook, you will have to take down that flag.

[McCook:] I am the American Consul. Why should I take down the flag?

[Davis:] Because I am the Custom Inspector for this government, and I am not going to do business in a building where that [US] flag is flying. I never did do that and I never will. That flag must come down, unless the Union Jack flies above it.

[McCook:] The consul's office is American territory. An English flag never floated above the stars and stripes on American territory and it never will if I can prevent it.

In the end, McCook moved offices and "Canadian officials have since taken occasion to assure McCook that Davis 'did not mean what he said'." 47

In tone and outcome, this was strikingly different from an episode in Skagway. That incident involved a Canadian collector of customs raising a British flag outside his office. Not being a diplomat, the Canadian had no right to raise a flag, though, coming from a friendly nation, he might do so provided that it flew beneath an American flag that was "at least as large, and as attractive as to color" as the British emblem.

Such was the stuff of diplomatic nicety, but national feeling got involved and there was "fear of trouble." The customs flag was hauled down and trampled; the agent was threatened and warned to fly the flag only beneath an American one. A treasury department agent observed that Americans in Skagway were not happy with their own government's neglect of Alaskan affairs but they were less happy about inaccurate intimations from Canadians that Skagway was on the point of being annexed by Canada. The Skagwayans were "all very loyal and proud of their country and almost worship the flag of the United States" and they fully believed "in fostering sentiment as taught by the speeches of the President," Theodore Roosevelt. The brief fury, which attracted the attention of the US secretary of the interior and secretary of state, along with Alaska's governor and other officials, ended up signifying not very much, except that British flags-in this case, the Canadian "Customs Revenue flag" - were hoisted in Alaska at some risk. ${ }^{48}$ To this writer's knowledge, nothing comparable happened in the Yukon Territory, even when American flags festooned Dawson's shop fronts. 
It cannot be that the Yankee flags in Dawson did not affront some Britons' and Canadians' sensibilities. Nearly half of the police force in the Yukon in the years 1895-1897 had been born in Britain. ${ }^{49}$ Is it possible that they did not care that Americans hoisted their flags to the point where it was sometimes difficult for people looking at photographs to know that Dawson was on British soil? Or consider Lord Minto's trip to Dawson - "that remote portion of Her Majesty's domain" - to investigate conditions. ${ }^{50}$ Walking through elaborate bunting the locals had set up, the earl saw a British flag highest and central, but was it possible that he missed the numerous Yankee standards in the same place? ${ }^{51}$ Elizabeth Robins described the lord's lady as a "woman who should go gliding through the world ... with banners waving over barges." In the Yukon many of the banners would be American. ${ }^{52}$

Why would representatives of Britain's empire tolerate this? It could not have been that they did not think of the Empire. In 1896 Charles Constantine, trailblazer of law and order in the Far Northwest, wrote an official report from "the most northerly military or semi-military post in the British Empire." ${ }^{53}$ Canadian parliamentarian Alfred Thompson wrote of surveyor William Ogilvie's work as developing "the Yukon for Canada and the Empire." ${ }^{54}$ And while it seems that Harwood Steele's history of policing in the Far Northwest, published in 1936, is more overtly patriotic than his original sources, his claims do not seem anachronistic. For him, an all-Canadian route to the Yukon was a "Path of Empire"; he described Mounties as serving "in the Queen's name"; and he wrote that at the turn of the twentieth century the Yukon Territory was "singing ... a thunderous March of Empire." He emphasized the importance of hoisting the British flag in Arctic places visited by American whalers who would see not only the Canadian Mounted Police force's prestigious uniforms but would be reminded of "the power of Canada and the Empire." 55

Why did not Canadian authorities in Dawson make the British flag more prominent, ordering down American flags or intentionally overwhelming them numerically as Constantine did in the Arctic after learning that French missionaries had hoisted the French Tricolour? ${ }^{56}$ Why no rule stating that no American flag could fly in the Yukon unless posted beneath a British one?

Why no reports of intercultural fisticuffs, as had been seen in Hawaii when some Britons were irked by the Americans' strengthening position in the islands? Navy officer Lucien Young reported on an episode in 1893 when Yankees in Honolulu precipitously raised the US flag and declared the islands a protectorate. President Grover Cleveland refused to support 
the act and the annexationist movement was set back for a time, but not before British residents indicated their feelings against the United States and a Canadian newspaper editor in the city issued "abuse of the United States officials." Rumours went forth that an English fleet was on its way to Honolulu with the intention of hoisting England's flag over the Hawaiian queen's palace. American and British sailors engaged in drunken fights, and it "became necessary to deprive the men of both the American and English ships of their liberty on shore for the time being." ${ }^{57}$ Why, so far as we know, no such incidents in Dawson?

William Morrison suggests, in passing, that Canadian authorities tolerated the flags as a matter of prudence: the Yankees were too numerous, and their country was too much on the rise, to provoke. ${ }^{58}$ William Ogilvie wrote in 1893 that Canada needed to establish authority over the region's gold fields "or we might ... have to face annoyances, if not complications, through possession ... by American citizens." ${ }^{59} \mathrm{~A}$ brief, evocative sentence in a letter from Flick and Tuck Flaherty suggests an American assumption that British-Canadian authorities would not make direct moves against the US flag. They described Indigenous people in the Tagish Lake area flying the Stars and Stripes and "Queen Vic. wouldn't do a thing if she knew it." ${ }^{\prime 00}$ An anti-imperialist editorial published in the Los Angeles Herald sarcastically criticized Britain for "Anglicizing the auriferous [gold-bearing] deposits of the Yukon" - as if the gold of the Klondike rush were not already British. ${ }^{61}$

It seems clear that many Americans in Dawson effectively forgot, or chose not to notice or remember, that they were in a region under a different country's jurisdiction. Certainly many were surprised to discover that the Yukon Territory was part of the British Empire. William Ogilvie recounts conversations in St. Michael, Alaska, with Americans awaiting passage to the Yukon. He told them the North-West Mounted Police (NWMP) were in charge there. They asked who had sent the NWMP there, and "when told that it was the Canadian Government, they wanted to know what in __ [sic] the Canadian Government had to do with it." 62

An envelope stamped in 1907 and addressed to "Dawson City, Yukon Territory, Alaska" suggests that the geography lesson never really took hold, ${ }^{63}$ and frequent cross-border movement made the boundary's existence easy to forget. In one of his letters, Father Judge refers briefly to a frontier separating British and American territory (and he mistakenly wrote that Forty Mile was in British Columbia), but his letters do not clearly indicate that his last religious mission was in Canada. ${ }^{64} \mathrm{He}$ had written while in Alaska that he was "reminded by the flag" that that 
"remote corner of the Union" was American. One wonders if the US flags in Dawson caused him almost to forget that he was now in the British Empire. A published collection of his letters includes a photo of Front Street. Along with the usual mud (or dust) and crowds of hat-bearing men, one sees seven flags, the two most conspicuous, and also the highest, being American. ${ }^{65} \mathrm{~A}$ reference in the priest's published letters to Dawson as the "most northern of American cities" contributed to the misperception. ${ }^{66}$

Morris Zaslow writes that between 1898 and 1900 Americans (or Americanized immigrants) probably comprised three-quarters of the estimated 40,000 people in the Yukon Territory. By 1901 the figure had fallen to about $32 \%$ and by 1911 to $22 \%$ - still a substantial minority. ${ }^{67}$ Charlotte Porsild estimates that the American-born (as opposed to those born in other countries who had emigrated to the US) made up about $30 \%$ of Dawson's gold rush population. ${ }^{68}$ However one looks at it, Yankees in the Yukon's most important town comprised a large and energetic group, and in that age of American expansionism, punctuated by an easy military victory against the Spanish Empire in 1898, it would have been at least risky to challenge the Yankee sense of self. In South Africa, Britain would fight a nasty war partly to ensure that natural resources stayed within the Empire. In the Yukon and Canadian Arctic, the most Britain would do was tax American takings in gold and whales. ${ }^{69}$

British authorities could not stop American occupancy in the Canadian Far Northwest, but they could indicate ownership. Thus in the early 1900s Canada sent forces to the Arctic, fearing that

if American citizens [were] permitted to land and pursue the industries of whaling, fishing and trading with the Indians without complying with the revenue laws of Canada and without any assertion of sovereignty on the part of Canada, unfounded and troublesome claims may hereafter be set up. $^{70}$

The emphases were on asserting Canadian sovereignty, albeit usually in a non-provocative manner, and on gaining tax revenue from economic activity. What Canadians and the British Empire may have lost in pride, they gained in tax revenue and the avoidance of conflict with Yankees. From the British perspective in the years 1896-1905, this was probably as good as things could be. 
This suggests undercurrents of tension and dislike. What there was of these was sometimes rooted in international comparison. A letter written in 1897 by an American named Frank Miles was critical of Canadian plodding. "There are four parties of Governmental Engineers here," he wrote.

People here think they are going to [create] a pack trail or wagon road. They are going to make a survey for a Rail road, but they are slow, fearful slow. If the Klondyke was on the other side of the line the Americans would have had a Railroad to it by this time."

More than anything else, the Americans were galled by Canadian taxation. "A large amount of gold will go out this year," wrote Father Judge,

and the prospects are good for some years to come; yet the royalty and the heavy taxes discourage many from working their claims, the owners hoping to get the royalty off by next year. This will prevent many new men from getting work, and keep the country back. Many are going to seek their fortune in the American territory, where they will have much more ground and little or no taxation. ${ }^{72}$

Tuck Flaherty complained about Canadian fees and advised people back home not to bother with the Yukon Territory. "It is daylight robbery from the [White Pass] summit until you get out, and we are going over to God's country," by which he meant Alaska. ${ }^{73}$

William Ogilvie also used the term "God's country" to refer to lowertax Alaska. Canada's mining-claim recording fee of \$15 seemed unjust when compared to Alaska's \$2 version. But Ogilvie noted that some Canadians and "Britishers" felt the same way and also preferred Alaska, so anti-tax feeling did not always comport with national identity. ${ }^{74}$ And Flaherty's grief notwithstanding, he did not soon abandon British territory.

A few thought that American security in Alaska compared favourably with the Yukon. "The facts are," an American journalist reported, "that a marshal with a deputy or two in citizens' clothes keeps as good order in the Nome camp under the stars and stripes as the scores of red-coated, mounted police do under the union jack and the Canadian flag on the British side." 75 But this seems to have been a minority opinion. 


\section{Co-operation \& Conversion}

More common was appreciation for Canadian order as represented by the Canadian Mounted Police. These men were not perfect. The Flaherty brothers describe a long line of boats tied up and awaiting Mountie inspection. "Instead of waiting two or three days," they write, "we told our troubles to a policeman and threw him a dollar. The blow killed John Bull. Our outfit was inspected and we were onward sailing in thirty minutes."76 A seemingly minor infraction, this instance of Mountie looseness nevertheless stands apart from the usual story recounted in the literature of the day.

Women's memoirs and diaries, especially, sound this theme. In the late 1890s, Anna DeGraf drifted across the Alaska-Canada boundary "without thinking anything about it," as she had done a few years before, but this time she noticed a customs house. Loaded with provisions but lacking money, she considered the problem of having to pay the duty required of non-Canadians. Then she had an idea. "I told Johnnie to get out his trombone and play "God Save the Queen!" and the rest of us would stand in the boat and sing it." DeGraf had "read a good deal about Queen Victoria and had always admired her for her good deeds," and she thought the song might lift the Mounties' spirits.

So Johnnie played and rest of us sang as our boat touched the shore. Out came those strapping big fellows ... and stood still and [took off their hats] while we finished singing. As we landed, they all came down to meet us with smiles and hearty handshakes. They invited us into the house and fed us well. We stayed a day with them, and such a rest and comfort and pleasure it was! I learned later from experience that nothing too good can be said about the Canadian officials in the Yukon. The lives they saved, their kindness to travelers, their courtesy and honor have never been excelled. In Dawson ... I made many a fur coat for the Canadian Mounted Police, and how proud I was of those coats - and of those men! ${ }^{77}$

DeGraf added that the Mounties were "always on the lookout for travelers," they provided security for women travelling to and from Dawson, they protected people from wild animals, and on one occasion a Mountie saved her from drowning. There was some crime in Dawson's first years, she wrote, "although it is remarkable the way the Canadian Mounted Police kept order." She remembered the Mounties as cordial, 
dutiful, courageous, and persevering. When "once assigned to a case, they never let up until they find their man, whether the search takes them to South Africa or any other part of the globe." 78

Martha Black recalled first meeting Mounties at the Canadian border: "I thought that finer, sturdier, more intelligent-looking men would be hard to find." The order they kept was impressive when compared to the "lawlessness" of gold rush Alaska. Mounties escorted miners bearing large amounts of gold, regardless of nationality, and thus helped to construct their "world famous reputation." She wrote of the Mounties' "brilliant uniforms" and recalled that "everybody [obeyed] an order from the Mounties." ${ }^{79}$

Along with respect came elements of romance, illustrated in telegrams between Americans in Washington and the Yukon Territory. One American promised that she would "not to break [a] redcoated [sic] Mountie if you let me play with him." Another wrote: "Our hats are in Alaska but our hearts are with you ... But you won't be lonesome any more. We are saving a red coated Mountie for you." ${ }^{80}$

\section{Conversion}

The era 1867-1900 was marked by American assertiveness, and while relatively few Americans would exchange their national allegiance for a British or Canadian one, the case of Martha Black shows that some did. She had gone to the Yukon pregnant and separated from her husband. He died in Hawaii and she, somewhat reluctantly, married a Canadian miner, lawyer, and future member of parliament. (She herself would eventually represent the Yukon in Ottawa.) Her change of marital status forced a change of geopolitical commitment. "I am a firm believer in the principle that married couples ... should be in complete harmony in religion, in country, and in politics," she wrote. "So immediately after my marriage, without compunction, I became an Anglican, an Imperialist, and a Conservative." ${ }^{81}$ When American, Black had felt no compunction about taking gold from British territory; when Canadian, she expressed concern, during a sojourn in British Columbia, that an agent for the Smithsonian Institution might take fossils from Canada, and she wrote her opinion to authorities in Ottawa. ${ }^{82}$ In her memoir, Black recounts the sense of outrage that came on the heels of Dawson's first robbery. The crime was bad enough, she notes, but the indignity was heightened for happening "under the Canadian flag, indeed under the very noses of the Red Coats." So it was that a young woman proud in her heritage as a Daughter of the 
American Revolution came to express anger at an affront to "red coats." 83 This was true conversion.

A less forceful example comes from Elizabeth Robins, an Americanborn actress whose diary reveals a definite partiality for England: she adopted British spelling even in private writing; she associated with influential Britons such as the Scottish-born Canadian magnate and parliamentarian Lord Strathcona; and England's influence on her was sufficient to lead a Briton travelling in Alaska to assume that she herself was English. She acknowledged that she was not in fact English but "I've lived in England and I love England." Her brother, a minister in Nome, once joked that a US flag hoisted over a post office had been "put up in your honour," suggesting a Union Jack might have suited her better. And after a day of July Fourth speeches about the United States and its recent military successes against Spain and insurgents in the Philippines, the two of them agreed that "a vast deal of bunkum is talked on this anniversary in our country." But Britain's war in South Africa evinced more positive feelings. As "we passed the British Port [at] Vancouver," she wrote, she was happy to know that a round of cannon salutes signified celebration of a British military success. She was "awfully glad" for this, even if her "hurrah" was muted in deference to the Americans among her. At St. Michael's she wrote in her diary that Nome, where she had spent much time, was already "farther away from me than London." 84

In other cases, British identities came second-hand, the result of long living on British territory. In March 1916 a certain Henry Nicodet sent a letter to the secretary of the British Empire Club in Dawson. Canadians were fighting with Britain in the First World War, which the United States had not yet joined. Nicodet, an American, claimed to have been blacklisted from employment in Dawson and thus from the possibility of earning "bread and butter for my family." "I am in truth an American citizen who came to this country in ' 97 and have been with the country ever since with its ups and downs," he wrote. He had raised his children in the Yukon Territory with his wife who was "English to the back bone." He had "two nephews at present fighting in Flanders for liberty," he continued, and "I have a son here who has put his name down to be sent to the front." The club could take his name off its blacklist, he concluded threateningly, or he would "take steps and raise a hornet's nest about your ears that would rather be left dormant in these troublous times. ${ }^{85}$ The club secretary informed Nicodet that he had misunderstood its policies and, so far as we know, the problem went away. 


\section{Control \& Mutual Dependence}

Nicodet's experience, whatever accounts for it, points to the fact that by the First World War de facto American pre-eminence in the Yukon had passed. What existed by 1914 was clear British-Canadian control in the Yukon, clear American control in Alaska, and mutual dependence in the many matters that crossed the international boundary.

Canadian control is illustrated by correspondence related to American flags in Dawson. In mid-1917, Alfred Thompson, the Yukon's member of parliament, received guidance from the secretary of state's office "relative to the flying of the American flag on the Administrative Buildings in the Yukon." This was important because the United States had recently entered the First World War on Britain's side. In the previous April, and for the first time in history, the Stars and Stripes had been hoisted "from the highest tower of the Parliament Buildings at Westminster" in London as well as on "all the [Canadian] Government buildings, on the Premier's residence and on the private and business houses throughout [Ottawa] the Stars and Stripes waved beside the Union Jack." ${ }^{\prime 86}$ The Yankee flag being posted prominently in the national and imperial capitals, it was impossible that this could not be allowed in the Yukon. But however it was done, the Yukon's American-born population would not decide.

Thompson learned that no regulations on the matter existed. As for Americans in the United States, they would never allow their flag to appear subordinate. "I have been in Washington frequently of late on the occasion of the reception of the British, French, Italian, and other missions," the writer noted, "but I never saw at any time a foreign flag given precedence over the flag of the country." He referred to the American flag at Westminster Tower in London, "but that was an exceptional-nay, unprecedented-occurrence, in order to mark the great occasion of the United States entering the war." It was time for a clear flag policy for the Yukon, and here it was:

the British flag should always fly from the chief flag staff of the Yukon building, and if it is considered desirable to fly the American flag as well, it should be flown from another flag pole and slightly lower than the British flag. I would avoid putting it directly underneath the British flag; but ... it might be flown on one side of the British flag, on a separate flag pole and slightly lower. It would serve rather to balance things if, when the American flag was flown, the French flag was flown as well..$^{87}$ 
This was June 1917. The next month, the occasion of the Fourth of July led to a change in protocol in Dawson. It was fine, on US holidays, to fly the US flag, "but both flags must always be flown at the same height whether on the one flagpole or separate poles." 88

The days of Yankees posting flags in the Yukon where and as they pleased had long ended. American and British flags were posted togethernot only in Canada and England but in the United States, including Alaska, where the two emblems were marched in parade, though the British one clearly in second place. ${ }^{89}$

Even in earlier years, talk of potential conflict between Britain and the United States shared news space with reports of international accord. During the Spanish-American War, there had been pro-American celebrations in Canada. Mary Hitchcock records in her diary that "everyone" in Dawson was eager to hear about the US war heroes, ${ }^{90}$ and some 2,000 people gathered at the Central Congregational Church in Toronto sang "God Save the Queen" and the "Star Spangled Banner," and heard remarks to the effect that the "Anglo-Saxon race," Americans and Britons together, were engaged in the "great work ... liberating the oppressed and throwing wide the commerce of the world." ${ }^{\prime 1}$

Even when there were localized tensions in the Far Northwest, Canadians and Americans relied on, sometimes depended on, one another. We saw that the Anglican missionary William Bompas was not enthusiastic about the Americans taking possession of Fort Yukon, but while the Hudson's Bay Company was prohibited from further trading at the post, Bompas continued to use the fort as a base of operations. On at least one occasion, his wife spent eight months at the fort. ${ }^{92}$ Indeed, Fort Yukon appears regularly in Canadian and American sources, for it was a vital stopping point up and down the Yukon River, visited regularly by residents, miners, traders, tourists, and officials en route to or from Circle City, St. Michael, Dawson, and numerous other spots. When authorities feared famine in the winter of 1898, Dawsonites were sent to Fort Yukon where food shipped from the US government was to be stored.

Another kind of cross-boundary co-operation involved the transportation of criminals and the insane. In April 1901, George Perry, a US marshall in Alaska's third district and based in Eagle City, sent a letter to authorities in Dawson asking for permission to transport prisoners through the Yukon Territory to Skagway. "As it is now," Perry wrote, "we have to take our prisoners out by the way of St. Michael, and then to Seattle, which is a round about way of going out." The request was passed to H. Ross, commissioner of the Yukon Territory, who was further informed that the 
United States had been accommodating when Canada had requested that criminals be "turned over to us at the Boundary ... without the formality of taking out extradition papers." For these and other reasons, the NWMP agent wrote, "I would like to send a favorable reply to the US Marshall." 93 Through 1916 a pro forma process was in place: a telegram from US authorities requesting permission to transport detained persons through the Yukon, followed quickly by a return telegram granting permission.

At a more mundane level, people in the Far Northwest were bound together by the region's hardships. To live in northeastern Alaska or the Yukon was to be "cut off from the outside world," as if one were "in China or the interior of Africa." ${ }^{\prime \prime 4}$ Anna DeGraf described at one point feeling as if she was "locked up in Siberia, and the key lost." ${ }^{95}$ Especially before the rush of 1898 brought modern amenities to the Far Northwest, life's difficulties there evinced reflection on the vagaries of life as captured in famous sayings: "all is not gold that glitters" and "never a rose without a thorn." 96 It seemed that everyone knew someone who had lost body parts-ears, noses, fingers, or feet-to freezing. ${ }^{97}$ Martha Black wrote of the "men of the North" without national distinction, their common identity forged in fights against scurvy and waist-high snow drifts. ${ }^{98}$

Perhaps worst of all were the mosquitoes. "I often long for a temperature of $50^{\circ}$ of $60^{\circ}$ below zero," wrote Kennicott, "that I might be relieved from them. It is not cold, but the mosquito, that is the hardest thing to endure in the north." ${ }^{99}$ Alexander Murray, founder in 1847 of Fort Yukon, recorded his impressions: "I sat smoking my pipe and my face besmeared with tobacco juice to keep at bay the d----d mosquitos still hovering in clouds around me, that my first impressions of the Youcon [sic] were anything but favorable." ${ }^{100}$ Father Judge tells us that the mosquitoes' reign of terror sometimes threatened to forestall Mass. ${ }^{101}$ For William Bompas, "the mosquitoes were bad, and caused his temples and the back of his ears to stream continually with blood." ${ }^{102}$ Mary Hitchcock writes of going for a walk, "but the mosquitoes were so ravenous and attacked us in such swarms, that we beat a hasty retreat." The conversation with her "English friend" that followed probably had more to do with common life in the Far Northwest than with national differences. ${ }^{103}$

The path to such sentiment had been long paved by commonality of language and literature. ${ }^{104}$ Before leaving for the Yukon, Martha Black was told that she would face "danger, privation, and sorrow" in a foreign land, but also that she would be among English-speaking people, which obviously would make for ease of communication and greater human understanding. This conversation between English speakers drew on a 
shared literary culture. Diaries and memoirs from the time refer to British authors-George Eliot, Thackeray, Dickens, and Walter Scott-and some considered their experiences in light of literary works like Daniel Dafoe's Robinson Crusoe and Robert Louis Stevenson's Treasure Island. ${ }^{105}$

The fact that small communities like Circle City had more than one newspaper reminds us that miners and manual labourers were readers; Shakespeare was a cultural staple. Anna DeGraf records that after a time of song on a Christmas Eve "[one] of the men read from Shakespeare" while others danced. ${ }^{106}$ Elizabeth Robins recorded her reflections on Coriolanus without a hint that doing so on the Yukon River was out of place. ${ }^{107}$ In passing, miners' letters employ phrases from As You Like It and Hamlet. ${ }^{108}$

Even the illiterate were familiar with myriad phrases from the King James Version of the Bible, and allusions to biblical passages conveyed meanings that are lost to readers lacking a knowledge of so foundational a cultural text. When Harwood Steele wrote of "fishers of men," of "wolves in sheep's clothing," of men being buried "without a prayer by Good Samaritans," of his father, Sam, who went "down unto the people," like Moses, and "spake unto them," and of preachers' warnings about Dawson tempting a fate similar to "its wicked sisters, Sodom and Gomorrah," he was referring to well-known biblical themes and stories that did not need recounting. ${ }^{109}$ The same was true when William Ogilvie employed the phrases "sackcloth and ashes" and "cast the dust from their feet."110 When miner Flick Flaharty described a man aboard ship during a storm as "doing the Jonah act in dead earnest," he would not have had to explain the allusion. ${ }^{111}$ When William Bompas wrote that trade associated with boom town Forty Mile (Ch'èdà Dëk) seemed a fulfilment of "the seemingly [utopian] promise 'I will make the wilderness like Eden'," he did not have to explain his meaning. ${ }^{112}$

The biblical allusions did the work and almost everyone, pious or not, caught them. ${ }^{113}$ Thus Martha Black did not think it strange to relate giving birth in Dawson and the kindness of "uncouth men" - miners and prospectors who brought food, olive oil, and gold dust-to the ancient story of a "Holy Mother and her Babe, born in a manger, and the gifts of frankincense and myrrh brought to her by the wise men."114 BritishCanadians and Yankees shared a culture of high biblical literacy that went beyond a collection of sayings, phrases, and tropes. It may be that not many who went to the Far Northwest were overtly pious (sincere expressions of religious devotion in memoirs, diaries, and other sources are rare), yet many would have agreed that the Bible addressed, in a 
common language, the most basic questions of life. Americans organized themselves according to democratic principle-discussion, votes, majority rule; British-Canadians emphasized official authority. Both pledged allegiance to a moral law, expressed by the Golden Rule found in the New Testament: "Do as you would be done by," ${ }^{115}$ which happened to become the motto of the Yukon Order of Pioneers.

The point should not be pressed too far. As Abraham Lincoln had noted in his second inaugural address of March 1865, the fact that Americans of the north and south "read the same Bible" did not prevent them from hurling staggering death at one another; and Britons and Yankees of the American Revolution and War of 1812 eras had surely been equally, if not more, biblically literate. But just as certainly, a common language, literature, and treasure trove of sayings, catch phrases, and figures of speech could be drawn on to enhance understanding and deepen intercultural affinity.

\section{Anglo-American Relations}

In the broad background was an idea, widely dispersed if not generally embraced, that the English-speaking peoples should draw closer together, perhaps even merge into a sort of Anglo-Saxon league of nations. The energy behind the idea seemed to come mainly from within a British Empire poor in friends and rich in challenges. At the time of the SpanishAmerican War, London's Daily Mail had observed that the United States enjoyed Britain's support "at a time when France, Germany and Russia are backing Spain as fully, and almost as openly that, as they are opposing British efforts for freedom of foreign trade throughout the world."116 Around the same time, the Prince of Wales stated his desire to see a permanent alliance between the United States and Britain that would benefit all concerned and would, the prince said, be relatively easy to maintain, helped along as it would be by similar "race habits" and shared commercial interests. "We desire a formal alliance; it is an alliance that is most natural, for blood is thicker than water."117

The British strategist G.S. Clarke envisioned a "naval league" between the two English-speaking nations, the impact of whose commerce was felt around the world. Together, the countries would "dictate ... peace throughout the sea highways of the world." British commercial interests would benefit from American order in the Western Hemisphere and the Pacific, Clarke wrote. Five years before Hawaii's annexation, he had declared that the islands "must become American soil." Americans, in turn, would benefit from British holdings. Clarke observed that the British 
harbours sprinkled around the globe were "ready to become resting, coaling, and refitting stations for United States ships."118

Some hoped that the United States and the British Empire could fully reunite. Cecil Rhodes, that British imperial activist of special drive, wished for "the recovery of the United States for the making of the Anglo-Saxon race but one Empire." 119 Later, the Scottish-born American industrialist Andrew Carnegie envisioned a joining of the United States, Canada, and Britain into a "Re-united States" or a "British-American Union." The separation of the thirteen American colonies, Carnegie wrote, had been a mistake and needed to be undone. Writing in 1893, he recognized that this "may all seem Utopian," and his claim that "Canada would undoubtedly favor" union with the United States-as would Wales, Scotland, and Ireland - was not well-informed. US Senator John Sherman of Ohio could have told him so. ${ }^{120}$ In 1888 Sherman had said that he "firmly believed" that Canada would join the United States. But when asked if he thought this would happen any time soon, the senator's candid response was, “No, I suppose not."121

Unrealistic as Carnegie's proposal was, it nevertheless brought the thought of greater Anglo-Saxon unity to a wide reading public. The idea lurked to the eve of the First World War. "There is not an intelligent, sincere mind in the British Empire or the United States," argued the Washington Herald in 1912, "but knows that Anglo-American reunion would be the greatest blessing that could be bestowed on mankind."122 Just as Virginia and Maryland surrendered territory for the site of the US federal government, so could Canada and the United States cede land for an Anglo-American capital. "The Canadian peninsula adjoining Niagara Falls, with an equal area on the American side, would make an admirable site." 123

\section{Proposal to Cede the Alaskan Panhandle}

The sense that the English-speaking peoples should unite in sentiment and purpose, if not politically, partly informs a proposal for the cession of the Alaskan panhandle to Canada. The plan appears to have been the work of a certain Robert Stein of Baltimore, and it found favour with one-term US Congressman Frank Smith, whose district included parts of Baltimore.

The plan found support among professors and peace advocates. Some said that the cession should be made on the centennial of the Treaty of Ghent (1815), which had ended the War of 1812. Some suggested that the Alaska panhandle was nearly useless to the United States, and argued 
that if the US held onto that "unnatural vermiform appendix" when it could do Canada much more good, then that would be a "disgrace to common sense."124 Others acknowledged the significance of Juneau, Sitka, Skagway, and other Southeast Alaskan sites, but argued that the sacrifice would be worth the international goodwill gained. It was true that the salmon fisheries were important, one writer noted, casually adding without argument that the "industry will be better cared for under Canadian rule." 125

A skeptical Fairbanks Daily Times had noted in the late summer of 1911 that such a deed would end a "constant source of frustration" to Canadians in northern British Columbia and the Yukon Territory who, post-cession, would be able to trade from Ketchikan, Wrangell, and Skagway without crossing a national boundary. ${ }^{126}$

This was the age of the Social Gospel. Charles Sheldon's novel In His Steps (1896), read widely in Canada, counselled a way of life driven by the question What would Jesus do? The Vancouver Daily World linked the book to "a growing consciousness of the brotherhood of mankind."127 In this spirit, some asked what Jesus would do with the Alaska panhandle. The obvious answer is that he would give it to Canada. Such was the simple application of the Golden Rule to international affairs. If a strip of land comparable to the panhandle hung south from eastern Canada, then Americans, blocked from the sea, would very much want that barrier to the seas removed. So the United States should treat Canada the way it would want to be treated. ${ }^{128}$ In doing so, proponents said, the US would "gain immensely in prestige" for having initiated "a new era in national courtesy," and Canadians could be certain that annexationist feeling in the US had finally burned out. ${ }^{129}$

Opposed to the plan were "swaggerers and jingoes," the "stubborn, sluggish, cross-grained, twisted, lopsided, narrow and thick-skinned."130 Such types were unable to see the great possibilities-for example, that ceding the panhandle to Canada would pave the way toward the abolition of war. News of the magnanimous sacrifice would flash around the world and princes and paupers alike would be awakened to a new global possibility. "If we donate the Panhandle to Canada now," wrote L.L. Friedrich of Washington, DC,

and thus give tangible proof of our earnestness, there is every reason to think that the astounded nations will pause their wild orgy of slaughter to ask: "Why can't we settle our differences in a gentlemanly way, as the Americans are doing?"131 
In the words of another advocate, the plan afforded "a hope-inspiring example of that higher type of statesmanship which alone can save mankind from appalling disasters." 132 Still another supporter reflected that, had the proposal been made before the First World War began, "it is quite possible that the ... war might have been avoided."133

It is not surprising that Canadians who knew of the plan favoured it. Alfred Thompson, the Yukon member of parliament, hinted at the psychological discomfort involved in having to cross a thin strip of American territory to get from the Yukon to the Pacific Ocean. The panhandle, Thompson offered, "belongs geographically, climactically, socially, and from the standpoint of its natural resources, to British Columbia and Yukon Territory." Britons and Americans were about to celebrate one hundred years of peace, he said, and "it seems to me a fitting time to bring this matter of boundaries to the attention of both countries."134

If there had been a prize for enthusiasm on the topic, the Edmonton Journal would have earned it:

What has hitherto been a geographical absurdity, an economic nuisance, a source of irritation and bitterness, is hereafter to be known as the New Palestine, Earth's Holy Land of Peace. Through it, not only are Yukon Territory and the northern half of British Columbia to gain free access to the Pacific Ocean, but humanity is to gain free access to the ocean of peace. The grotesque Appendix is to become the immortal pattern by which our European kindred may learn how the limbs of contiguous nations may be swathed in boundaries that will not chafe. ${ }^{135}$

In the background, of course, was the resolution of the Alaska-British Columbia border dispute of the twentieth century's first years. Almost completely forgotten to Americans, the decision regarding the boundary marks an important moment in Canadian history. Well told in numerous places, the story need not be recounted here. Suffice it to say that the Canadian response to the fact that the one Briton on the tribunal deciding the matter had sided with the three Americans against the two Canadians was one of deep discontent. "Canadians rightly believed that their interests had been sacrificed on the altar of Anglo-American amity."136

Canadian Secretary of the Interior Clifford Sifton had written that "practically whatever the United States demands from England will be conceded." 137 It was substantially true: Venezuela, Hawaii, the Philippines, Panama, and now the Alaska-British Columbia border. (The fact that the 
US had the better argument is beside the psychological point.) Something similar had been seen in the Far Northwest: Yankees planting US flags almost at will on British soil.

Congressman Smith's panhandle scheme promised to soothe Canadian feelings. Not all advocates were interested in simple charity. Some said that, rather than giving the panhandle to Canada, it could be traded for British Honduras (Belize). Others added that Belize, once American, could then be traded to Mexico for Baja California, which would give Arizona access to the sea. ${ }^{138}$

And the plan was not all sweetness. Some of its proponents argued for greater Anglo-Saxon unity in the face of a perceived Asian threat. The concern was wrapped in the social Darwinian language of the day, such as when the Reverend George Haslam wrote that it was foolish for "white nations to be engaged in ... war, the Eastern menace being what it is." ${ }^{139}$ The language is off-putting, and yet it is true that three decades later Canadians and Americans would together confront the Japanese army and navy in a colossal, brutal war.

Advocates said that the panhandle exchange would set an example to a troubled world thirsty for peace; it would forge or strengthen bonds of affection between Britons and Yankees as they led the world toward democracy and the rule of law; and, in removing a source of irritation between English-speaking peoples, it would make preparation for an eventual showdown with East Asia easier. In one way or another, the English-speaking peoples should pull closer together.

Such armchair musings found little support on Capitol Hill in Washington, DC. An Oregon newspaper offered a curt summary: "The Smith resolution is being ignored by most members of Congress and will not be acted on by the committee on foreign affairs."140 Most Alaskans considered the plan the "limit and pinnacle of absurdity." "141 The few who paid attention to the unfolding story assumed that Smith's preoccupation with the scheme probably helped to account for the loss of his congressional seat after just one term. ${ }^{142}$

The idea briefly re-emerged in the context of the Paris peace talks in 1919, though only among Canadians. If the US president Woodrow Wilson could ask Italy to surrender part of Dalmatia to Yugoslavia, Canadian army chaplain John J. O'Gorman wrote to Canada's prime minister Robert Borden, then surely the president would be amenable to letting Canada have Alaska's panhandle. Borden was reportedly "fascinated" by the concept, but there is no evidence that Wilson ever heard of it, ${ }^{143}$ and so the scheme died. 
Almost two weeks after the US Congress voted to enter a war on the side of Britons and Canadians who had been fighting for some three years, the Winnipeg Tribune contemplated the United States and Canada, "neighbors in peace for over a century, closer today than ever before in personal and international good fellowship." 144 Uncritical acceptance of that sentiment required forgetting about several US presidents who had rehearsed aloud their assumptions that Canadian annexation to the United States was inevitable; it meant forgetting about President Theodore Roosevelt's whispered military threats during the Alaska-British Columbia boundary dispute; and it meant forgetting that, for many Americans, Canada amounted to a geographical figment of the imagination. As a journalist for the Toronto Globe visiting Washington, DC, put it, "To the average American in public life the Dominion does not exist." 145

Agreeing that Canada and the United States had been "neighbors in peace for over a century" required forgetting about the Fenian raids from the US into Canada in the aftermath of the Civil War. This may have been difficult for Henry Boldoc and Daniel Glass, Dawson's aged veterans of the raids. ${ }^{146}$

And yet, for all the tensions and rumours of tensions, Canadians and Americans mingled. William Ogilvie noted that clashing national identities sometimes caused trouble in the Yukon but that Yankees and Canadians both considered saloons a much greater problem. ${ }^{147}$ William Bompas was not glad to see Americans at Fort Yukon in 1869, and he was never happy about the presence of non-Indigenous people in the Far Northwest, but in January 1895 he had to confess that the short-lived, mostly American boom town of Forty Mile brought a relatively luxurious diet to the region. "California is the fruit garden of the world," he wrote, and "we have the fruits of California as fresh as when gathered and preserved in cans." ${ }^{148}$

In the Yukon Territory, Canadians provided infrastructure and security; Americans - via, for example, the Alaska Commercial Company provided most of the connections to a global economy. Sometimes Americans and Canadians argued or swapped resentful looks. More often they co-operated and conversed in words shaped by a common literary, religious, moral, and political heritage.

Before the First World War's eruption in August 1914, Martha Black was sarcastically asked "how long one has to be a daughter of the American Revolution before becoming a daughter of the Empire." ${ }^{149}$ She called 
the question "impertinent" and proved during the war that her onceYankee heart was now all with Canada linked to Britain. When she and other attendees at a theatre party in Dawson learned in August 1914 that Britain was at war, the crowd, led by "scarlet-coated" Mounties, felt an "overwhelming urge" to sing "God save the King." "Although 8,000 miles of mountain, land, and sea separated us from London, the heart of Empire," she wrote,

yet England's King was our King, and England's Empire was our Empire. We realized as never before that we were not English, not Irish, nor Scotch, nor Welsh, nor yet Canadians, but British, bound together by the Anglo-Saxon ties of blood. ${ }^{150}$

Not many Americans would swap identities so completely. And perhaps Black's conversion was not as total as it seemed. At her own request, her coffin, guarded at her funeral by Mounties, was draped, half and half, in the Union Jack and Stars and Stripes. ${ }^{151}$

Author

Preston Jones is professor of history at John Brown University in Arkansas, United States.

\section{Notes}

1. William Bompas to George, 6 Aug 1869, Bishop Bompas Fonds mss 125 (81/38), Yukon Archives, Whitehorse. In addition to the sources cited, the author has consulted the following general works: Ken S. Coates and William R. Morrison, Land of the Midnight Sun: A History of the Yukon (Montreal \& Kingston: McGill-Queen's University Press, 2005); and Melody Webb, Yukon: The Last Frontier (Vancouver: University of British Columbia Press, 1993).

2. William R. Morrison and Ken S. Coates, "Introduction to H.A. Cody," An Apostle of the North (Edmonton: University of Alberta Press, 2002 [repr., 1908]), lvi and lxxvi.

3. Evening Bulletin, 1 Apr 1867.

4. Times reproduced in Evening Bulletin (San Francisco), 17 May 1867.

5. $\quad$ Times-Picayune (New Orleans), 14 Dec 1867.

6. Daily Evening Bulletin, 11 Dec 1867; Flake's Bulletin, 15 Dec 1867; The Sun (Baltimore), 25 Dec 1867; Trenton Star Gazette, 28 Aug 1867.

7. Reported in the Daily Kansas Tribune, 20 Nov 1869.

8. Leroy McQuesten, Recollections of Leroy McQuesten (n.p., n.d.), 1.

9. Morrison and Coates, "Introduction," xlv. 
10. Laurier quoted in Bruce Hutchinson, The Struggle for the Border (New York: Longmans, Green and Co., 1955), 439.

11. Julia McNair Wright, Among the Alaskans (Philadelphia: Presbyterian Board of Publication, 1883), 30.

12. Quoted in Michael Gates, Gold at Fortymile Creek: Early Days in the Yukon (Vancouver: University of British Columbia Press, 1994), 25.

13. Judge, 130.

14. Victoria Joan Moessner, ed., The Alaska-Klondike Diary of Elizabeth Robins, 1900 (Fairbanks: University of Alaska Press, 1999), 54, 71, 78, 110, 135, 157, 206.

15. James Alton James, ed., The First Scientific Exploration of Russian America and the Purchase of Alaska (Chicago: Northwestern University, 1942), 113

16. Anna DeGraf, Pioneering on the Yukon, 1892-1917, ed. Roger S. Brown (Archon Books, 1992), 10.

17. R.N. DeArmond, ed.,"Lady Franklin Visits Sitka, Alaska, 1870,” The Journal of Sophia Cracroft Sir John Franklin's Niece (Anchorage: Alaska Historical Society, 1981), xxviii.

18. Ibid., 5 .

19. Mary E. Hitchcock, Two Women in the Klondike (Fairbanks: University of Alaska Press, 2005 [repr., 1899]), 74 \& 91-92.

20. This section suggests the value of considering the gold rushes of 1896-1900 within the broad context of Britain-US relations. The suggestion is also made in Morris Zaslow, "The Yukon: Northern Development in a Canadian-American Context," in Regionalism in the Canadian Community, 1867-1967, ed. Mason Wade (Toronto: University of Toronto Press, 1969), 188-189

21. "Important Treaty with the Sandwich Islands," New Hampshire Patriot and Gazette (Concord), 17 Jul 1867.

22. “Looking for a Trade," Sioux City Journal (Iowa), 2 Dec 1898.

23. Henry Watterson, History of the Spanish-American War (New York: Western W. Wilson, 1898), 277.

24. Alfred Thayer Mahan, The Interest of America in Sea Power, Present and Future (Boston: Little, Brown \& Company, 1898), 68.

25. Ibid., 84 .

26. Ibid., 86.

27. Bradford Perkins, The Great Rapprochement: England and the United States, 1896-1914 (New York: Atheneum, 1968), 185.

28. Archibald Cary Coolidge, The United States as a World Power (New York: Macmillan Company, 1927 [repr., 1908]), 238.

29. Reported in the Morning Oregonian (Portland), 17 May 1867.

30. Martha Louise Black, My Ninety Years (Anchorage, 1976), 109.

31. George Adams, Life on the Yukon, 1865-1867 (Kingston: Limestone Press, 1982), 55 and 129. 
32. Charles J. Judge, An American Missionary: A Record of the Work of Rev. William H. Judge (New York: Maryknoll, 1904), 66-68.

33. Moessner and Gates, Alaska-Klondike Diary, 261.

34. Ibid., 3 .

35. Ibid., 133.

36. Children's float, 4th of July celebration, 1915 Nome, Alaska, Wien family papers, University of Alaska Fairbanks archives, accession \# 2010-50-25.

37. July 4th Cape Nome, 12 o'clock at night, 1900, Edward Mulligan photograph album, University of Alaska Fairbanks archives, accession \# 1961-1018-61.

38. Parade in Dawson; William Sale collection, University of Alaska Fairbanks archives, accession \#1979-106-9.

39. "Klondike-The Rush for Gold," Virtual Museum Canada, accessed 15 April 2016, http://www.virtualmuseum.ca/sgc-cms/expositionsexhibitions/klondike/English/main.html

40. Photo posted at "Klondike Gold Rush," Wikipedia, accessed 15 Apr 2016, https://en.wikipedia.org/wiki/Klondike_Gold_Rush

41. Photo titled "Dawson City during the Gold Rush late 1890s," Pinterest, accessed 15 Apr 2016, https://www.pinterest.com/ pin/275071489715011885/?from_navigate=true

42. Winnipeg Tribune, 14 Jul 1899.

43. Vancouver Daily World, 18 Apr 1898.

44. Black, My Ninety Years, 55.

45. Robert A Friedrich (US attorney, Juneau) to John G. Price (assistant US attorney, Skagway), 26 Jun 1901; "Alaska File of the Special Agents Division of the Department of the Treasury, 1867-1903" (microfilm), file M802, roll 13.

46. Hitchcock, Two Women, 95.

47. Leader-Democrat (Springfield, MO), 21 Oct 1898.

48. See Friedrich to Price; John Brady (Alaska governor) to Secretary of the Interior, 29 Jun 1901; and J.F. Evans to Secretary of the Treasury, 18 Jul 1901; "Alaska File of the Special Agents Division of the Department of the Treasury, 1867-1903" (microfilm), file M802, roll \#14.

49. William R. Morrison, Showing the Flag: The Mounted Police and Canadian Sovereignty in the North, 1894-1925 (Vancouver: University of British Columbia Press, 1985), 66.

50. Topeka Daily Capital, 5 Aug 1900.

51. See the photo in Moessner and Gates, Alaska-Klondike Diary, 265. In the photo I count ten flags associated with Britain and eleven US flags.

52. Moessner and Gates, Alaska-Klondike Diary, 272.

53. Quoted in Morrison, Showing the Flag, 22.

54. William Ogilvie, Early Days on the Yukon (Whitehorse: Wolf Creek Classics, 1913), 302. 
55. Harwood Steele, Policing the Arctic: The Story of the Conquest of the Arctic by the Royal Canadian Mounted Police (London: Jarrolds, 1936), 31, 38, 82, and 97.

56. Morrison, Showing the Flag, 79.

57. Lucien Young, The Real Hawaii (New York: Doubleday \& McClure, 1899), 212-218.

58. Morrison, 64. Norman Penlington makes a similar argument. See his Canada and Imperialism, 1896-1899 (Toronto: University of Toronto Press, 1965), 98.

59. William Ogilvie, Early Days on the Yukon (Whitehorse: Wolf Creek Books [reprint], 1913), 144.

60. Charles J. Roehr, ed., Klondike Gold Rush Letters: Along the Trail of '98 from Dyea, Alaska, to Dawson, Yukon Territory (New York: Vantage Press, 1976), 19.

61. Los Angeles Herald, 20 May 1898.

62. Ogilvie, Early Days on the Yukon, 220.

63. Envelope from Camden New Jersey addressed to Dawson City Yukon Territory, Alaska. Dawson Museum archives, accession \#: 2014-36.1.

64. Judge, An American Missionary, 73 and 128

65. Ibid., $118-119,162 \& 227$

66. Ibid., 200.

67. Zaslow, "The Yukon," 196.

68. Charlotte Porsild, Gamblers and Dreamers: Women, Men and Community in the Klondike (Vancouver: University of British Columbia Press, 1998), 71.

69. Ged Martin has noted, though without commentary, that "In the Yukon gold rush ... the British displayed nothing of the aggressive expansionism seen in South Africa." See Martin's “Canada from 1815," Oxford History of the British Empire: The Nineteenth Century, ed. Andrew Porter (Oxford: Oxford University Press, 1999), 527.

70. Department of the Interior memo quoted in Morrison, Showing the Flag, 78.

71. Frank Miles to William MacBride, 22 Sep 1897, MacBride Museum, Whitehorse, Yukon Territory.

72. Judge, 221

73. Roehr, Klondike Gold Rush Letters, 28.

74. Ogilvie, Early Days on the Yukon, 207.

75. Indianapolis News, 9 Sep 1905.

76. Roehr, Klondike Gold Rush Letters, 19.

77. Anna De Graf, Pioneering on the Yukon, 1892-1917 (Hamden, CT: Archon Books, 1992), 64.

78. Ibid., 66, 67, 70, 103, 104.

79. Black, My Ninety Years, 29, 56, 64, 71, 76.

80. Telegrams dated June $10 \& 11,1929$. Daughters of the Golden North collection, accession \# HMC-0483. University of Alaska Anchorage archives. 
81. Black, My Ninety Years, 75.

82. Ibid., 94 .

83. Ibid., 2 \& 65 .

84. Moessner and Gates, Alaska-Klondike Diary, ix, 47, 49, 70, 92, 133, 209.

85. Henry Nicodet to secretary of the British Empire Club, 30 Mar 1916, File 30553, Yukon Archives, Whitehorse, Yukon Territory.

86. Ottawa Journal, 20 Apr 1917.

87. Undersecretary of State to A. Thompson, 19 Jun 1917, Yukon Archives, Whitehorse, Yukon Territory, File 31169 vol. 28.

88. Deputy Minister of the Interior to G.N. Williams, 4 Jul 1917, Yukon Archives, Whitehorse, Yukon Territory, File 31169 vol. 28.

89. Photo of parade in Fairbanks, Urban Collection, Anchorage Museum, box 3, accession no. B64.1.525

90. Hitchcock, Two Women, 74, 92, 107.

91. San Francisco Call, 31 May 1898.

92. H.A. Cody, Apostle of the North: Memoirs of the Right Reverend William Carpenter Bompas (New York: E.P. Dutton and Co., 1908), 287.

93. NWMP superintendent to H. Ross, Commissioner, 29 Apr 1901; Transporting Americans through the Yukon, File 2485, Yukon Archives, Whitehorse.

94. Judge, 48.

95. DeGraf, Pioneering on the Yukon, 34.

96. Adams, Life on the Yukon, 175.

97. "Letter of Henry M. Bannister to his parents, 12 Nov 1866," in James, First Scientific Exploration, 269.

98. Black, 129.

99. James, First Scientific Exploration, 83.

100. Copy of handwritten report, Alexander Murray fonds, manuscript 5 (82/98), Yukon Archives, Whitehorse.

101. Judge, Missionary, 85

102. Cody, Apostle, 55.

103. Hitchcock, Two Women, 28.

104. The oft-made point is stated in the State Journal (Raleigh, NC), 27 Apr 1917.

105. Robins 70, 102, 145; Black 6, 19. Not all of the shared literature was first written in English. Charlotte Bompas, wife of Bishop Bompas, carried the works of Dante, in the original Italian, in her pocket into old age, and Harwood Steele organizes his narrative of gold rush Skagway partly around tropes taken from Dante's Inferno. See Morrison and Coates, Introduction to Cody, Apostle, lvii; and Steele, Policing, 17.

106. DeGraf, Pioneering on the Yukon, 84.

107. Moessner and Gates, Alaska-Klondike Diary, 137.

108. Roehr, Klondike Gold Rush Letters, 22 \& 51.

109. Steele, Policing the Arctic, 19, 47, 55 and 62. 
110. Ogilvie, Early Days in the Yukon, 198 and 206.

111. Roehr, Klondike Gold Rush Letters, 5.

112. William Bompas to George, 4 Jan 1895, Bishop Bompas Fonds, mss.125 (81/38), Yukon Archives, Whitehorse.

113. This is a theme in Preston Jones, A Highly Favored Nation: The Bible and Canadian Meaning, 1867-1900 (Lanham, MD: University Press of America, 2008).

114. Black, My Ninety Years, 45.

115. Gates, Gold at Fortymile Creek, 28 and 83.

116. Daily Mail excerpted in The Sun (Baltimore), 21 Mar 1898.

117. Morning World Herald (Omaha), 15 Mar 1898.

118. G.S. Clarke, "A Naval Union with Great Britain," North American Review 158:448 (Mar 1894), 362-363.

119. Cecil Rhodes, "Confession of Faith," in Sources of the Western Tradition vol. II (New York: Houghton Mifflin, 2006), 152.

120. Andrew Carnegie, "A Look Ahead," North American Review 156:439 (June 1893), 685-710.

121. Daily Inter-Ocean (Chicago), 6 Oct 1888.

122. Washington Herald (District of Columbia), 28 Jan 1912.

123. L.L. Friedrich, "Anglo-American Reunion," in Stop the War! Alaska Panhandle; Its Proposed Cession to Canada, no ed. (Washington, DC: Judd \& Detweiller, 1915), 56.

124. No editor, Stop the War! Alaska Panhandle; Its Proposed Cession to Canada (Washington, DC: Judd \& Detweiller, 1915), 66.

125. Ibid., 8 .

126. Fairbanks Daily Times, 5 Aug 1911.

127. Vancouver Daily World, 14 Feb 1901.

128. The Washington Herald (District of Columbia), 28 Jan 1912, offered maps.

129. Stop the War!, 6, 34, and 39.

130. Ibid., 13-14.

131. Ibid., 63.

132. Ibid., 68.

133. Ibid., 35 .

134. Ibid., 74-75.

135. Ibid., 79.

136. J.L. Granatstein, Yankees Go Home? Canadians and Anti-Americanism (Toronto: HarperCollins, 1996), 53.

137. Quoted in George Classen, Thrust and Counterthrust: The Genesis of the Canada-United States Boundary (Toronto: Longmans Canada, 1965), 339.

138. Fairbanks Daily Times, 5 Aug 1911.

139. Ibid., 17.

140. Morning Oregonian, 9 May 1914, 
141. William B. Stephenson, The Land of Tomorrow (New York: George H. Doran Company, 1919), 213.

142. Brainerd Daily Dispatch (MN), 4 Nov 1914.

143. Gaddis Smith, "The Alaska Panhandle at the Paris Peace Conference, 1919" International Journal 17:1 (winter 1961-2): 25-29.

144. Winnipeg Tribune, 18 Apr 1917.

145. Quoted in Classen, Thrust and Counterthrust, 328.

146. The records in the Yukon Archives at Whitehorse show that the two wanted a $\$ 100$ bounty the government made available to veterans of the raids. File no. 27978.

147. Ogilvie, Early Days on the Yukon, 247.

148. William Bompas to George, 4 Jan 1895, Bishop Bompas Fonds, mss.125 (81/38), Yukon Archives, Whitehorse.

149. Black, My Ninety Years, 103.

150. Ibid., 105.

151. Ibid., 141 and 163 (photograph). Black chose this herself. The American Legion Post at Skagway shipped an American flag to Whitehorse for the purpose. 